\title{
Growth to Early Maturity of Sugar Pine Trees Derived from Excised Mature Embryos Germinated In Vitro
}

\author{
by
}

\author{
Philip G. Haddock ${ }^{1}$
}

\begin{abstract}
Excised mature embryos of sugar pine (Pinus lambertiana Dougl.) of the 1940 seed crop from a single, open-pollinated tree in a natural stand in California were cultured on a nutrient-agar medium in 1941, transferred to forest soil, and outplanted in 1943 at the Eddy Aboretum of the Institute of Forest Genetics, Placerville, California. Development to the sapling stage was reported in 1954. This paper extends to 1979 the development record of the tree surviving several thinnings. The single remaining tree first produced fertile seed in 1977, and at an age of 39 years in Juné, 1979, was 25 $\mathrm{m}$ in height and $75 \mathrm{~cm}$ in diameter, bh. It has a long live-crown and gives every evidence of vigorous health. Similarity of seed source and planting site environments is suggested as one possible reason for excellent growth. Potential for ultimately normal growth to maturity of tissue and cell cultures of forest trees is believed promising.
\end{abstract}

\section{Résumé}

Des embryons exisés de Pinus lambertina Dougl. ont été développés dans un milieu de culture avec agar et éléments nutritifs en 1941. Ces embryơns provenaient de graines résoltées en 1940 sur un arbre individuel pollinisé naturellement. Ils furent transférés en sol forestier dès 1941 et repiqués en 1943 à l'ar. boretum Eddy de I'Institut de génétique forestière à Placerville en Californie. Le développement de ces tiges jusqu'au stade de gaulis ont fait l'objet d'un rapport en 1954. Le présent document fait le point jusquà 1979 sur l'arbre qui a survécu à plusieurs éclaircies. Le seul arbre restant de cette expérience a donné des fruits fertiles en 1972. II était alors âgé de 39 ans, avait $25 \mathrm{~m}$ de hauteur, $75 \mathrm{~cm}$ de diamètre à hauteur de poitrine, portait une longue cime vivante et montrait des signes évidents de bonne santé. L'excellente croissance de cet arbre pourrait être attribuée au fait de la similitude des sites entre a source de graines et le milieu de plantations.

Ainsi, il y a lieu de croire que la technique de cultures de tissus peut produire des arbres à croissance normale jusqu'à maturité.

\section{Introduction}

The purpose of this paper is to present the results of further development of sugar pine trees (Pinus lambertiana Dougl.) derived from excised mature embryos germinated in vitro and first reported when the trees had attained sapling size (Haddock 1954). In 1974, there were two surviving trees of the original eight at the outplanting site in the Eddy Arboretum of the Institute of Forest Genetics at Placerville, California. In 1979, only Tree No. 4 remained, all others having been cut at intervals in order to provide more growing spacing for the remaining trees. After essentially 39 growing seasons, this single survivor is 25 meters in total height and 75 centimeters in diameter, breast height. It produced fertile seed in 1977.

Recently, there have been a large number of investigations of various aspects of plant embryo, tissue and cell

${ }^{1}$ Faculty of Forestry The University of British Columbia Vancouver, B.C. V6T 1W5. culture, including woody plants (Steward 1968, Durzan and Campbell 1974, Winton 1972, Cheng and Voqui 1977). Some of these have included detailed studies of sugar pine seeds and excised embryo development (Berlyn 1967, Greenwood and Berlyn 1973, Baron 1973). However, so far as I know, there have been no reports in the literature of any forest tree embryo (or other tissue or cell-cultured material) grown to the size and age of the sugar pine tree reported upon here. Therefore, I think it is of interest to briefly review development of these trees and bring up-to-date the record with some details of the origin and condition of the surviving sugar pine tree.

\section{Methods and Results}

The work reported here grew out of a study of the rest period in seeds and buds of sugar pine (Haddock 1942). Mature embryos of sugar pine were excised from fresh, airdried, open-pollinated, mature seed from a single tree of the 1940 crop and grown on a nutrient medium of the composition shown in Table 1. This is given here because of errors in the original report discovered too late for an appropriate errata at that time. Some of the cultures received supplements, in milligrams per liter, of thiamin, 0.1 , pyridoxine 0.1 , nicotinic acid 0.5 , and glycine 3.0 . However, addition of these gave no apparent increase in growth over that on the standard medium (Haddock 1942). Therefore, this growth medium replaced, at least in part, the nutrients supplied during normal germination by the female gametophyte tissue.

Details of the embryo extraction and early development with photographs have been reported earlier (Haddock 1954). Following growth in glass jars on the nutrient medium in 1941 for 11 weeks (Tree No. 3) and 27 weeks (Tree No. 4), the plantlets (or "'seedlings') were transplanted after the hypocotyls and radicles had become lignified, to natural unsterilized surface soil from the mineral $(A)$ horizon of a northern Sierra Nevada forest site. After a few months' growth in containers in a greenhouse at Berkeley, California, the plantlets were transferred to a lath-house at the Institute of Forest Genetics early in 1942, and placed under the care

Table 1.

Nutrient agar medium

\begin{tabular}{lc}
\hline \multicolumn{1}{c}{ Substance } & Concentrations in $\mathbf{g} / \mathbf{L}$ \\
\hline $\mathrm{Ca}\left(\mathrm{NO}_{3}\right) 2 \cdot \mathrm{H}_{2} \mathrm{O}$ & 0.111 \\
$\mathrm{MgSO}_{4} \cdot 7 \mathrm{H}_{2} \mathrm{O}$ & 0.0718 \\
$\mathrm{KNO}_{3}$ & 0.080 \\
$\mathrm{KCL}_{2}$ & 0.065 \\
$\mathrm{KH}_{2} \mathrm{PO}_{4}$ & 0.0125 \\
$\mathrm{MnSO}_{4} \cdot 2 \mathrm{H}_{2} \mathrm{O}$ & 0.00545 \\
$\mathrm{ZnSO}_{4} \cdot 7 \mathrm{H}_{2} \mathrm{O}$ & 0.00267 \\
$\mathrm{H}_{3} \mathrm{BO}_{3}$ & 0.00160 \\
$\mathrm{FeSO}_{4}$ & 0.0025 \\
$\mathrm{KI}$ & 0.00075 \\
SUCROSE & 40.0 \\
DIFCO-BACTO AGAR & 6.0 \\
\hline
\end{tabular}


of Dr. N. T. Mirov. He transplanted them to the field in May 1943 , to a site a few meters immediately to the north of the Institute Headquarters Building. The elevation of the Institute is 823 meters above sea level (a.s.I.) and the mean annual precipitation is about $890 \mathrm{~mm}$. Summers are long and dry; winters are mild and rainy, with occasional heavy, wet snow up to about $510 \mathrm{~mm}$ in depth (Duffield and Righter 1953). Both the seed source and the planting site areas are classified by Küchler on his map of the Natural Vegetation of California (Barbour and Major 1977) as within the type number 7 (Sierra Yellow Pine Forest) or the ecotone between this and type number 25 (Blue Oak-Digger Pine Forest). The soil at the Institute of Forest Genetics is an Aiken Clay loam (Duffield and Righter 1953). Although the trees were probably watered during the first few summer periods to assure early survival, they were not subsequently irrigated or fertilized intentionally.

Available growth records in height and diameter for Trees No. 3 and 4 are shown in Table 2 .

The appearance of the trees, up to December 1950, has been illustrated earlier (Haddock 1954), and the development of Trees No. 3 and 4 by the summer of 1969 is shown in Figure 1. The single survivor, No. 4 is illustrated in Figure 2, as it appeared in June 1979 at the age of 39 years.

The stump of Tree No. 3, which was felled in 1974 is pictured in Figure 3. Its dimensions are; height $45.7 \mathrm{~cm}$, average diameter outside bark $63.5 \mathrm{~cm}$. The number of annual growth layers shown is 29 . The total age in 1974 was 34 years.

Since some of the height measurements given in Table 2 depended upon travel schedules, the measurements do not always show the maximum height and diameter attained that year. However, as Fowells (1941) indicated, a large percentage of the seasonal height growth in sugar pine (about 60 per cent) was obtained by June 30th in his study at $1585 \mathrm{~m}$, a.s.l. in the central Sierra Nevada. Since the Institute of Forest Genetics is situated at a lower elevation (823 m, a.s.l.) it is probable that the percentage of height growth attained by late June may be somewhat higher there. The excellent growth produced by these trees is doubtless due to a favorable combination of many factors. Among these probably, is the care taken by a number of the staff of the Institute of Forest Genetics over a number of years, including the timely removal of competing trees. Of the eight trees outplanted, only one died in the early years (of unknown causes), and by 1946 seven trees remained. In 1949 (or 50?) three were cut, and by 1961 only two trees, Nos. 3 and 4 were left. In 1974 or early 1975, No. 3 was felled, to provide for the fuller development of the taller No. 4

In 1969, Tree No. 4 produced male strobili, and in 1977, a number of mature cones and fertile seed were produced by Tree No. 4. This is in agreement with the reported general age of initial seed production for the species (40-60 years), according to Daniel et al. (1979).

It is interesting to note that in 1979 , at an age (in growing seasons) of 39 years, the single surviving tree (No. 4) compares very favorably in size with the average dominant forest tree on high sites (Site A-200) according to Fowells (1965), based on Dunning's (1942) studies. At 40 years, Dun- ning's table shows a height of $25 \mathrm{~m}$. and a diameter (bh) of $33 \mathrm{~cm}$ for average dominants in stands. Although the heights are identical, "my" tree has a considerably larger diameter $(75 \mathrm{~cm})$, probably due to it being essentially opengrown and now having a large proportion of its height in live crown (See Figure 2).

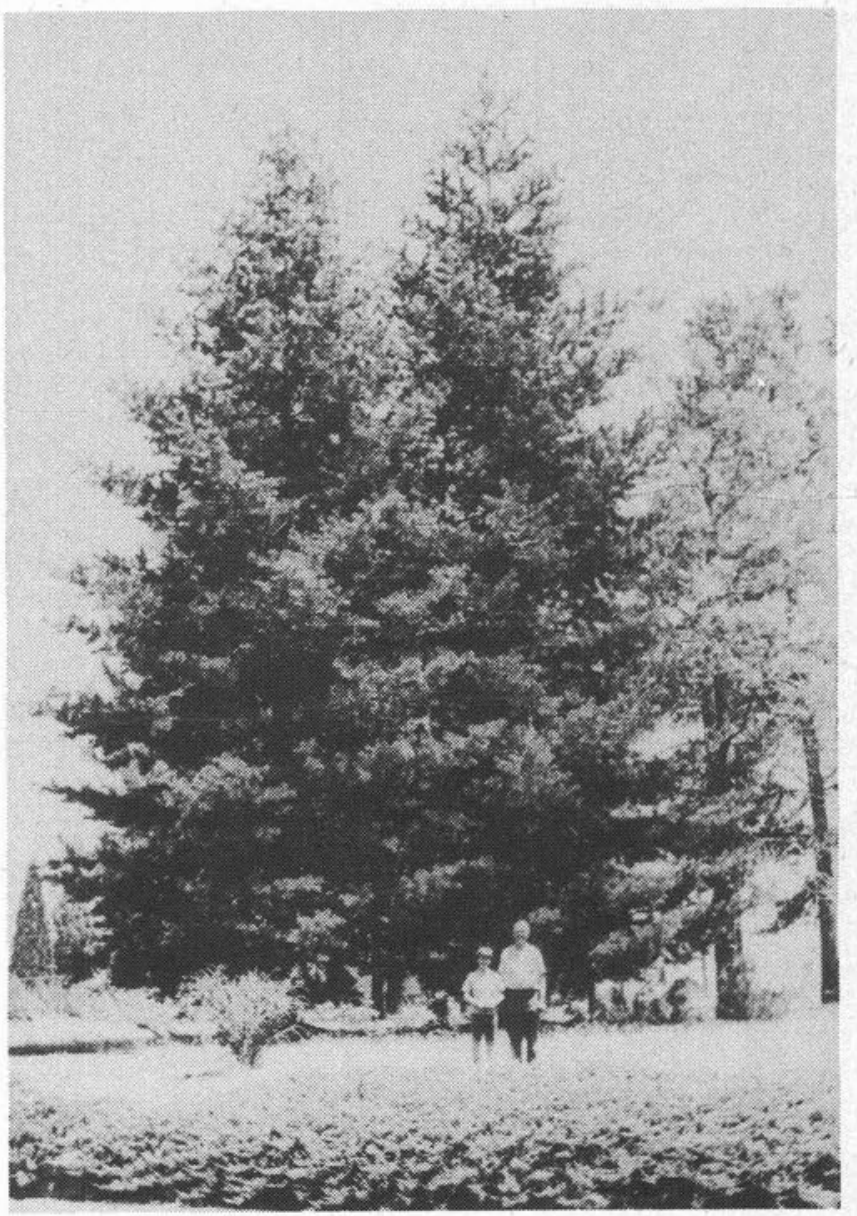

Fig. 1 Tree No. 3 at left, No. 4 at right. Photo July 8, 1969. Total heights 16.8 and $19.2 \mathrm{~m}$. respectively. Diameters B.H. 47.5 and $50.3 \mathrm{~cm}$.

\section{Discussion}

One may suggest several possible reasons for the initial survival in soil and the excellent early growth in the field of these embryo-cultured sugar pines. The survival in transplanting to soil may be due partly to leaving the plantlets on the nutrient agar until lignification of the hypocotyl and radicle had occurred. A further possible value was in the use of unsterilized, natural forest soil as a growth medium, thus providing possible sources of mycorrhizal fungi. Also, I think part of the success may be attributed to the close relationship between the environment of the

Table 2. Heights and diameters of sugar pines derived from excised, mature embryos germinated in vitro.

$$
\text { Total Heights (m) }
$$

Diameter Breast Height (cm)

\begin{tabular}{|c|c|c|c|c|c|c|c|c|c|c|c|c|}
\hline $\begin{array}{l}\text { Tree } \\
\text { No. }\end{array}$ & $\begin{array}{c}\text { Feb. } 12 \\
1946\end{array}$ & $\begin{array}{c}\text { Jun. } 24 \\
1946\end{array}$ & $\begin{array}{c}\text { Jan. } 27 \\
1949\end{array}$ & $\begin{array}{c}\text { Dec. } 28 \\
1950\end{array}$ & $\begin{array}{l}\text { Aug. } 15 \\
1961+\end{array}$ & $\begin{array}{l}\text { Jul. } 8 \\
1969\end{array}$ & $1974^{\star}$ & $\begin{array}{c}\text { Jun. 27. } \\
1979\end{array}$ & $\begin{array}{l}\text { Aug. } 15 \\
1961+\end{array}$ & $\begin{array}{l}\text { Jul. } 8 \\
1969\end{array}$ & $1974^{*}$ & $\begin{array}{c}\text { Jun. } 27 \\
1979\end{array}$ \\
\hline $\begin{array}{l}3 \\
4\end{array}$ & $\begin{array}{l}0.30 \\
0.30\end{array}$ & $\begin{array}{l}0.58 \\
0.43\end{array}$ & $\begin{array}{l}1.40 \\
1.58\end{array}$ & $\begin{array}{l}2.38 \\
2.71\end{array}$ & $\begin{array}{l}10.4 \\
11.0\end{array}$ & $\begin{array}{l}16.8 \\
19.2\end{array}$ & $\begin{array}{l}20.4 \\
21.3\end{array}$ & $\overline{25.0}$ & $\begin{array}{l}26.7 \\
26.7\end{array}$ & $\begin{array}{l}47.5 \\
50.3\end{array}$ & $\begin{array}{l}61.0 \\
66.0\end{array}$ & $\overline{75.2}$ \\
\hline
\end{tabular}

* See Mirov and Hasbrouck (1976), page 5.

+ Measured by L. Roche. 


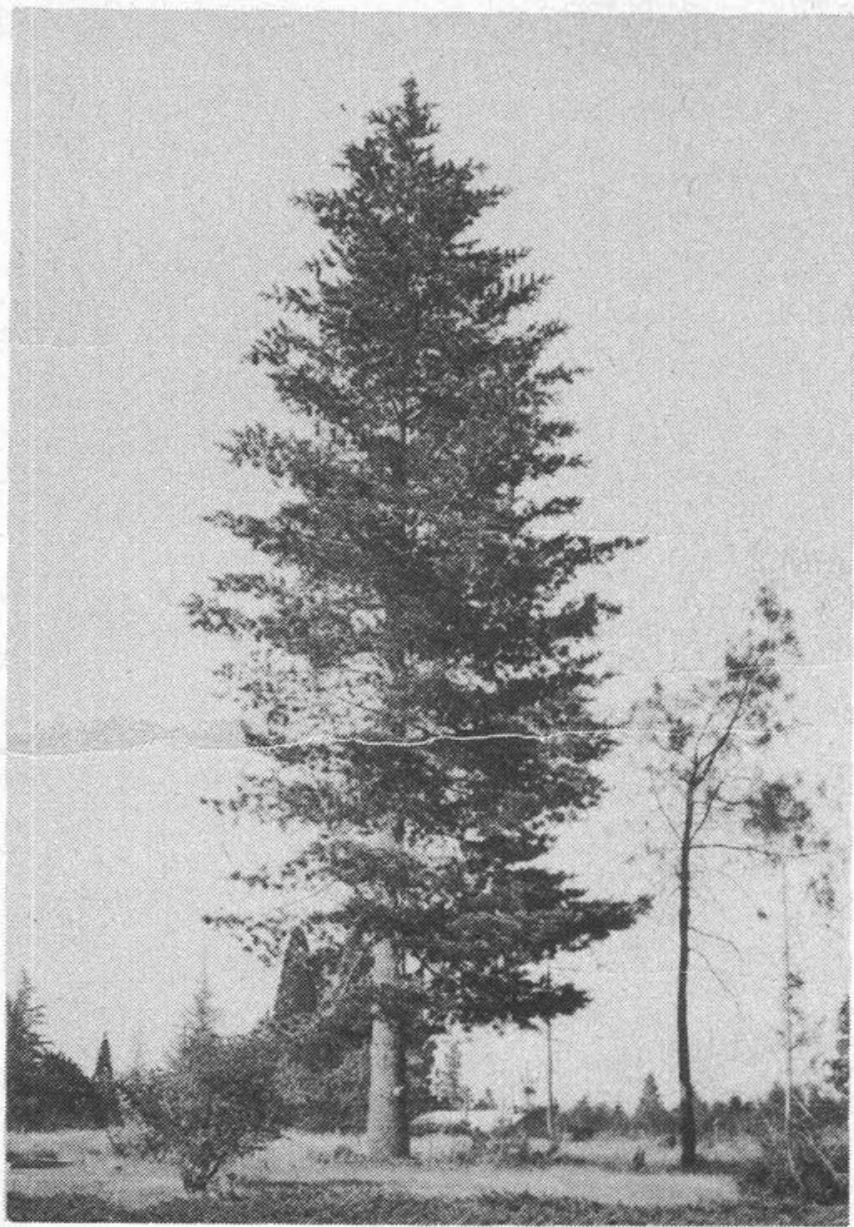

Fig. 2 Tree No. 4. Photo June 27, 1979. Total height $25.0 \mathrm{~m}$. Diameter B.H. $75.2 \mathrm{~cm}$. Note cap on trunk for scale. chymatous, meristematic, living plant cell. A brief survey of the literature of the past thirty years emphasizes the progress achieved in technique, and in the rapid increase in biochemical and physiological knowledge. According to at least one view (Durzan and Campbell 1974), the future prospects are bright for mass production of forest trees through cell and tissue culture.

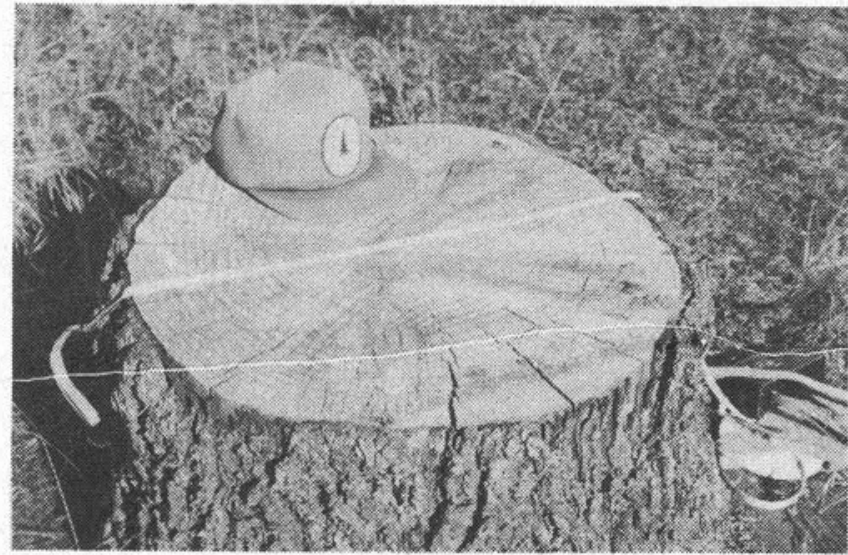

Fig. 3 Stump of Trees No. 3. Photo June 27, 1979 Diameter outside bark: $63.5 \mathrm{~cm}$. Total age when cut 34 years. Stump shows 29 growth layers.

\section{Acknowledgements}

The author is indebted to many people for assistance over a period of years in caring for, helping to measure and keep track of the trees, as well as for initiating and guiding the original investigation, or in reviewing the manuscript. These include: the late Professors J. P. Bennett, F. I. Righter and Dr. N. T. Mirov; as well as Drs. J. W. Duffield, W. B. Critchfield, Laurence Roche, John Worrall, Oscar Sziklai and Leroy Johnson.

\section{References}

original seed source and that of the planting site. The supposed seed tree from which I collected cones in September 1940 is located at an elevation of approximately $884 \mathrm{~m}$ a.s.I., $1.1 \mathrm{~km}$ west of the US Forest Service's Georgetown Ranger Station in the Eldorado National Forest. The site falls within Section 1, Township $12 \mathrm{~N}$. Range $10 \mathrm{E}$. of the Mt. Diablo Meridian, Eldorado County, California. The tree stands adjacent to the south side of the Georgetown Wentworth Springs road, about $4.8 \mathrm{~km}$ east of the Georgetown Post Office, on or near the old Ed Brauer farm.

The planting site described above is located on the northeastern outskirts of Placerville, California, roughly $25 \mathrm{~km}$ south-southwest from the seed-tree site. Climate and soil data for this location have been indicated above. The seed source environment and that of the planting site are thus believed to be approximately equivalent.

One is impressed with the potential for ultimately normal growth of embryo, tissue, and possibly cell-cultures of forest trees. It is true that some tissue and certainly single cell culture are far different from the mature embryo culture results illustrated here. It is also true that adventitious em. bryos produced in in vitro cultures may show great variability and abnormalities (Lutz 1971). However, I am reminded of the suggestive statement made some years ago in the University of California (Berkeley) plant anatomy classes of the late Dr. A. S. Foster. In the 1930's, he stressed the "totipotentiality" that may reside in the isodiametric, paren-
Barbour, Michael G. and Jack Major, 1977. The terrestrial vegetation of California. John Wiley \& Sons, N.Y. 1002 pp.

Baron, F. J. 1970. Metabolic patterns in dormancy and germinating seeds of sugar pine (Pinus lambertiana Dougl.) Advc. Fron. PI. Sci. 24: 47-64. For. Abst. 1973. 33'3. (Not seen).

Berlyn, Graeme P. 1967. The structure of germination of (Pinus lambertiana Dougl.) Yale University School of Forestry, Bulletin No. $71.36 \mathrm{pp}$, plus 49 fig. New Haven, Conn.

Cheng, Tsai-Ting and Thanh H. Voqui. 1977. Regeneration of Douglas-fir plantlets through tissue culture. Science 198: 306-307.

Daniel, Theodore W., John A. Helms and F. S. Baker. 1979. Principles of Silviculture. Second Edition. McGraw-Hill Co., N.Y. 500 $\mathrm{pp}$.

Duffield, J. W. and F. I. Righter. 1953. Annotated list of pine hybrids made at the Institute of Forest Genetics. For. Res. Note No. 86. California Forest and Range Experiment Stations, For. Serv., USDA, Berkeley. 9 pp.

Dunning, Duncan. 1942. A site classification for the mixed conifer selection forests of the Sierra Nevada. California Forest and Range Experiment Station Res. Note 28, 21 pp. For. Serv. USDA, Berkeley

Durzan, D. J. and R. A. Campbell. 1974. Prospects for the mass production of forest trees by cell and tissue culture. Can. Jour. of For. Res. 4:2:150-174.

Fowells, H. A. 1941. The period of seasonal growth of ponderosa pine and associated species. J. of For. 39: 601-608.

1965. Silvics of Forest Trees of the United States. Agriculture Handbook No. 271. 762 pp. For. Serv., USDA, Washington, D.C. 20250. 
Greenwood, M. and G. Berlyn. 1973. Pinus lambertiana embryo cuttings, I.A.A. - sucrose interaction in root regeneration. Am. J. Bot. 60: $42-47$.

Haddock, Philip G. 1942. A study of the rest period in seeds and buds of Pinus lambertiana Dougl. and Pinus jeffreyi Murr. Ph.D. thesis, University of California, $229 \mathrm{pp}$,

1954. Sapling sugar pines grown from excised mature embryos. J. of For. 52:6: 434-437.
Lutz, Albert. 1971. Aptitudes Morphogénétiques des Cultures de Tissus d'Origine Unicellulaire. Colloques Internationaux CNRS No. 193: 163-168 - Les Cultures de Tissus de Plantes.

Mirov, N. T. and Jean Hasbrouck. 1976. The story of the pines. Indiana University Press, Bloomington, London. 148 pp.

Steward, F. C. 1968. Growth and organization in plants. AddisonWesley Pulishing Co., Don Mills, Ontario. 564 pp.

Winton, Lawson L. 1972. Callus and cell cultures of Douglas-fir. For. Sci. 18:2: 151-154.

\section{Assessing the Accuracy of a Product-form Tree Volume Equation}

\author{
by \\ Peter Roebbelen and Victor G. Smith1
}

\begin{abstract}
In a continuing investigation of product-form as a predicting variable in volume estimation, this study compares a product-form tree volume equation with two standard volume equations and the Dominion Forestry Service form-class 70 and 75 volume tables in their ability to estimate individual tree red pine volumes. Using weighted regression and measurements from 3607 individual trees, coefficients for the three equations were developed. Freese's test of accuracy was used as the criterion of choice in deciding which method proved most accurate in estimating the volumes of a set of test data.

The product-form volume equation gave the most accurate estimates.
\end{abstract}

\section{Résumé}

Dans le cadre d'une recherche sur le "produit de forme" comme critère de prévision dans l'estimation du volume, la présente étude compare l'équation du volume de l'arbre basé sur le produit de forme avec deux équations standards et les tables de classe de forme 70 et 75 du Service forestier canadien, en vérifiant leur capacité d'estimation du volume de l'arbre individuel chez le pin rouge. Par régression et les mesures faites sur 3,607 arbres individuels, les coefficients de trois équations ont été calculés. Le test de précision de Freese a permis de déterminer quelque méthode donne le volume avec la meilleure précision. L'équation basée sur le produit de forme a été donné les estimés les plus précis.

\section{Introduction}

In his paper on the use of product-form 2 for stacked wood measurements on tree length logs, Smith (1976) concluded that the product-form volume equation ${ }^{3}$ gave more accurate estimates than the form-class volume, standard volume, or the regiona! volume/diameter equations which are used to estimate the volume of a given species over a broad range of site classes.

\footnotetext{
${ }^{1}$ The authors are, respectively, graduate student, and Professor of Forest Mensuration, both of the Faculty of Forestry, University of Toronto.

2Product-form $(P=d \cdot H)$ is defined as diameter outside bark at mid-height above breastheight (d) $X$ total height $(H)$.

3 product-form volume equations are the subset of form-class volume equations that use 3product-form volume equations are the subset of form-class volu
only $(d \cdot H)$ and diameter-breast-height as predicting variables.

${ }^{4}$ Smith, V.G. and A.F. Beckwith (1979, personal communication).

5 Site index is the dominant height at 50 years of age determined from an equation by Smith (1978, personal communication).
}

In contradiction, a subsequent study to assess the accuracy and bias of several volume estimates in red pine sample plots showed that the form-class volume tables currently in use were superior to the product-form equation (Smith and Beckwith, 1979). The information for that investigation was derived from stem analysis data, and therefore, the selection of sample plots was limited to those for which stem analysis was available. The use of stem analysis data to represent the smaller end of volume/diameter distributions at younger ages is questioned 4 .

This paper continues the investigation into product-form as a predicting variable for estimating volume. It is hypothesized that a product-form volume equation will estimate individual tree volumes better than standard volume equations and better than the widely used Dominion Forestry Service form-class volume tables (Anon., 1948).

Since all data were in English units, this study proceeded entirely in these units. However, the results have been converted to SI units according to Bowen (1974).

\section{Selection of Equations}

The product-form equation was compared with two models of standard volume equation, T.W. Dwight's six-term equation (Gerrard, 1966), and A.B. Berry's three-term equation (Berry, 1979):

$$
\begin{aligned}
& \text { DWIGHT } \\
& \hat{V}=b_{0}+b_{1} D+b_{2} H+b_{3} D H+b_{4} D^{2}+b_{5} D^{2} H \\
& \text { BERRY } \\
& \hat{V}=b_{0}+b_{1} D^{2} H+b_{2}\left(D^{2} H\right)^{2} \\
& \text { where, } \\
& D=\text { tree diameter at breast-height (Dbh) } \\
& H=\text { total tree height } \\
& b_{0}-b_{4}=\text { coefficients developed from regression }
\end{aligned}
$$

The Dominion Forestry Service form-class 70 and 75 total cubic-foot volume tables for red pine were also used in this comparison.

\section{Data Setup}

Individual tree measurements were used to develop the equation and individual tree volumes to test the hypothesis. Measurements of 3607 red pine trees were taken on trees felled during the course of thinning studies in red pine.

For each tree, measurements were obtained for Dbh (inches), d (inches), $\mathrm{H}$ (feet), as well as inside bark diameter measurements at the stump and 100 -inch intervals up the bole of the tree. Gross total volume (cubic feet) was scaled from these measurements. Stand information, such as age from plantings, site index 5 , and plot location, was also noted. The measurements were taken on trees felled in various red pine plantations in southern Ontario at various ages. The scaled volume is considered to be the true volume of the tree. The mid-height diameter (d) was estimated by inter- 